\title{
Coupling Microfluidic Platforms, Microfabrication, and Tissue Engineered Scaffolds to Investigate Tumor Cells Mechanobiology
}

\author{
Martial Millet ${ }^{\dagger}$, Raoua Ben Messaoud $^{\dagger}$, Carole Luthold and Francois Bordeleau *(1) \\ CHU de Québec-Université Laval Research Center (Oncology division), Université Laval Cancer Research \\ Center and Faculty of Medicine, Université Laval, Québec, QC G1R 3S3, Canada; \\ martial.millet.1@ulaval.ca (M.M.); raoua.ben-messaoud.1@ulaval.ca (R.B.M.); carole.luthold.1@ulaval.ca (C.L.) \\ * Correspondence: francois.bordeleau@fmed.ulaval.ca; Tel.: +418-525-4444 (ext. 15554) \\ + These authors contributed equally.
}

Received: 11 May 2019; Accepted: 19 June 2019; Published: 22 June 2019

\begin{abstract}
The tumor microenvironment (TME) is composed of dynamic and complex networks composed of matrix substrates, extracellular matrix (ECM), non-malignant cells, and tumor cells. The TME is in constant evolution during the disease progression, most notably through gradual stiffening of the stroma. Within the tumor, increased ECM stiffness drives tumor growth and metastatic events. However, classic in vitro strategies to study the TME in cancer lack the complexity to fully replicate the TME. The quest to understand how the mechanical, geometrical, and biochemical environment of cells impacts their behavior and fate has been a major force driving the recent development of new technologies in cell biology research. Despite rapid advances in this field, many challenges remain in order to bridge the gap between the classical culture dish and the biological reality of actual tissue. Microfabrication coupled with microfluidic approaches aim to engineer the actual complexity of the TME. Moreover, TME bioengineering allows artificial modulations with single or multiple cues to study different phenomena occurring in vivo. Some innovative cutting-edge tools and new microfluidic approaches could have an important impact on the fields of biology and medicine by bringing deeper understanding of the TME, cell behavior, and drug effects.
\end{abstract}

Keywords: tumor microenvironment; mechanobiology; microfluidic; microfabrication; extracellular matrix; tumor stiffness; tumor engineered models; disease modeling

\section{Introduction}

A tumor mass contains a heterogeneous population of cancer cells and infiltrating host cells such as endothelial cells, immune cells, fibroblasts, pericytes, adipocytes, or stem cells (Figure 1). Some types of tumor microenvironment (TME) cells can secrete factors and produce extracellular matrix (ECM) proteins which interact directly or indirectly with cancer cells. The mechanical and physical properties of the tumor microenvironment are increasingly appreciated as a key regulator of biological functions such as tumor growth, metastasis, and drug resistance. Accordingly, state-of-the-art microfabrication and microfluidic approaches have been developed to help uncover the underlying biological processes of cancer-associated mechanobiology.

In order to study crosstalk between cancer cells and TME in humans, bioengineers are using microfabrication and tissue-engineering microfluidics to biomimic TME. The aim is to reconstitute the architecture, the physical and chemical conditions, and the functional microsystem within a given tissue [1,2]. Moreover, heterogeneity of different cancer cell populations and the diversity of TME-associated cells constitute one of the major challenges for recreating the TME artificially. The 
heterogeneous architecture and anisotropic nature of the tumor ECM in vivo is another challenging aspect to recreating the TME. The main strategy is to control every condition and the whole infrastructure of reconstituted tissue to investigate dynamics of cancer development and therapeutic approaches coupled with constant perfusions of nutrients with a possible short-term analysis [3].

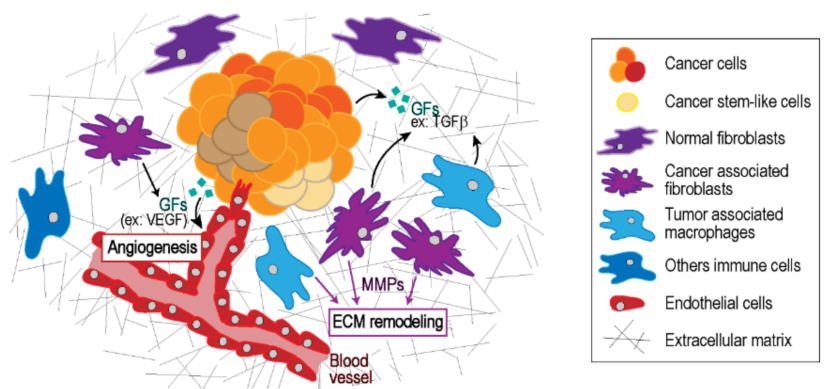

Figure 1. The tumor microenvironment representation. The tumor microenvironment (TME) is a considerably heterogeneous niche and consists of proliferating tumor cells, infiltrating immune cells, the surrounding extracellular matrix, blood vessels, and a variety of associated stromal cells. Intercellular communication within this niche is driven by a complex and dynamic network of soluble proteins. In solid tumors, these soluble proteins are synthesized by local tumor and stromal cells, including growth factors, angiogenic factors, extracellular matrix (ECM) remodeling proteins, chemokines and interleukins, and enhance tumor cell proliferation and invasion and inhibit tumor cell apoptosis.

Nowadays, cancer research and associated drug study are mostly conducted using two-dimensional and three-dimensional in vitro cell cultures and also animal models in vivo. 3D cell culture is getting slightly closer to understanding TME than the 2D monolayer harvesting method. 3D cell culture mimics basic biostructure and some ECM biomechanical and physiological properties, and also various parameters of TME can be modulated such as nutrient gradients and oxygen level [4-7]. In addition to the complication of microenvironment modeling, the limits of these techniques can be demonstrated through the gap between the success of many drugs in preclinical in vitro analysis and their breakdown in the patients. The study of animal models in vivo is time-consuming, expensive, inconsistently repeatable, and poses ethical issues [7]. The main advantage of this model is to work on a complete tumor microenvironment even if it does not reflect entirely tumor development in humans. Moreover, some specific models as immunosuppressed mice poorly mimic actual phenomena occurring in TME cells because immune cells play a primordial role in both pro- and anti-tumor responses [8].

Here, we reviewed the main features of the TME, ranging from the mechanical property alteration linked to tumor progression, mechanobiology of the cell response to soluble factors, as well as the different cellular contributor to the TME. We described the roles, advantages, and perspectives of applied microfabrication and tissue-engineered microfluidics that aim at recreating the complexity of the TME.

\section{Tumor Microenvironment}

Initiation, progression, and metastasis are the three stages of tumorigenesis which are influenced by the ECM and the overall biochemical state of the TME. The ECM provides architecture, elasticity, and strength to tissues. However, the ECM structure and chemical composition are regulated by a number of cell-mediated and enzyme-mediated processes. The actual ECM biochemical composition and biomechanical complexity are both tissue specific and linked to tumor progression [8,9]. Stromal enzymes irreversibly regulate ECM architecture crosslinking collagen and elastin fibers such as lysyl oxidase (LOX) and transglutaminase 2 (TG2) from which cells can reorient and cross-link collagen and elastin fibers $[10,11]$. The crosslinking of ECM components is largely responsible for the increased stiffness of the TME [12]. In addition, tumor associated macrophages (TAMs) and cancer associated fibroblasts (CAFs) secrete matrix metalloproteases (MMPs) as well as heparanase-promoting cathepsin L that act as ECM degrading protease, which in turn favor metastasis, angiogenesis, and 
inflammation $[13,14]$. Furthermore, CAFs, and to a lesser extent tumor cells, can secrete new ECM components and actively participate in remodeling the ECM architecture [15].

The tumor-mediated increase of ECM stiffness deregulates stromal homeostasis providing an acidic, hypoxic, or low-nutrient environment. At the same time, the stiffer ECM offers greater survival rate to tumor cells [8]. In fact, ECM stiffness plays a role in driving malignancy and influences the switch of stromal cell phenotypes [11,16-18]. Exact composition of tumor stroma fluctuates according to tumor type and tissue location, but the most abundant components of the ECM are collagen, fibronectin, laminin, proteoglycan, and hyaluronan $[8,13,19]$. Integrins are the main family of cell surface receptors which interact with ECM fibrils promoting cell adhesion, cell migration, cell proliferation, and cell survival [20]. The presence of specific integrins at the cell surface control to which ECM component the cells are able to attach [21]. In turn, ECM stiffness sustains tumorigenesis by assembling integrin-mediated focal adhesion (FA) complexes and stimulating integrin-dependent mechanotransduction $[17,22,23]$. Once activated, it promotes focal adhesion kinase (FAK)-associated pathways, cytoskeletal remodeling, and cellular contractility $[11,20,24,25]$.

The mechanical properties and composition of the ECM also influence how soluble factors contribute to tumor progression. In vivo, growth factors (GFs) can be found in either soluble form or bound to the ECM, including to structural proteins, such as collagen, and glycosaminoglycans [26]. ECM-bound GFs are more efficient to induce enhanced downstream responses with lower doses. This phenomenon is explainable by higher local concentration of ECM-bound GFs and covalent tethering of GFs to the ECM. With ECM-bound GFs, integrins can be clustered to growth factor receptors (GFRs) and enhance signaling by synergistic responses [26]. Interestingly, several signaling pathways triggered by chemokines, cytokines, and GFs, and which are known to induce cell growth and migration, are in fact modulated by cell contractility and ECM stiffness [13,14,27-30]. For instance, ECM stiffness-mediated cell contractility increases endothelial cell response to vascular endothelial growth factor (VEGF), which in turn can promote tumor associated angiogenesis and vessel permeability [12,31]. Alternatively, cell contractility can also increase the availability of otherwise unavailable GFs. For example, transforming growth factor $\beta$ (TGF $\beta$ ) is usually found to be encapsulated within the latency-associated peptide (LAP) bound to the ECM. When cells exert sufficient forces on a LAP complex bound to a stiff ECM, it will distort and unwrap causing the release of TGF $\beta$ in the TME [32]. Taken together, these data provide good examples on how ECM stiffness and cell contractility influence cellular responses to GFs but also partially affect GFs availability in the TME.

The TME also contains several types of stromal cells that interact with the ECM while playing an important role in supporting the tumor. First, malignant cells, myeloid cells, and CAFs produce angiogenic factors and stimulate sprouting of vascular endothelial cells [33]. Pericytes support vascular endothelial cells in neoangiogenesis [34]. In parallel, tumor-cell-produced VEGFC and VEGFD stimulate neogenesis of lymphatic vessels [35]. Then, perpetual inflammation state, wound healing features, and cancer cells attract different kinds of infiltrating immune cells. Metelitsa et al. showed that C-C Motif Chemokine Ligand 2 (CCL2)-producing neuroblastoma cell lines allow the infiltration of natural killer T cells (NKTs) [36]. B lymphocyte subtypes $\mathrm{B}_{10}$ and $\mathrm{B}_{\mathrm{reg}}$, tumor-associated macrophages (TAMs), and myeloid-derived suppressor cells (MDSCs) produce immunosuppressive factors such as interleukin 10 (IL-10) and interleukin 12 (IL-12), which are used by malignant cells to hide from immunosurveillance [37,38]. Moreover, MDSCs are known to trigger tumor-promoting phenotypes of TAMs [39]. Thirdly, adipocytes secrete adipokines, which promote cell survival [40], angiogenesis, and inflammation [41], but also provide fatty acids to the TME, fueling cell proliferation [42]. Finally, while transformation of fibroblasts into CAFs can be mediated by TGF $\beta$, microvesicles released by cancer cells can also induce fibroblast activation into CAF [43]. Moreover, this microvesicle-mediated CAF transformation also depends on the underlaying ECM stiffness [44]. Considering that all the different cell types within the TME contribute to tumor development [16,22], it is important to address cell-cell and TME-cell interactions in relevant tissue engineered models to fully grasp how tumor mechanical properties drive disease progression. 


\section{Use of Microfabrication and Microfluidic Systems to Engineer the Tumor Microenvironment (TME)}

Nowadays, animal models are still considered as the gold standard. However, controlling the TME in mouse models is inherently challenging due to the complexity, with few tools allowing perfect controls of TME components such as ECM stiffness or availability of soluble factors [45]. The alternative classical cell culture approaches offer a simplified system, which in turn lack the complexity observed in the disease. Historically, most findings obtained using classical approaches fail to translate into applicable treatments [46]. Thus, a major challenge to study the role of the TME in tumor progression is our ability to accurately mimic the in vivo environment in vitro. In this context, several new approaches have been adopted over the years in order to thwart the simplicity of plastic dish cell culture while allowing the precise control of biochemical and mechanical parameters not possible in animal models.

\subsection{D Microfabricated Substrate}

The simplest implementation of this idea of tuning an in vitro model to mimic the in vivo condition is achieved using 2D microfabrication techniques. Cell attachment is dependent on ECM components such as fibronectin, collagen, or laminin, which allow, for instance, integrin signaling pathways activation [47]. To better understand how the spatial organization of these ECM components influences cell adhesion and spreading, several groups have relied on photolithography microfabrication [48], a high spatial resolution photoprinting process [49,50], which allows the transfer of ECM features of controlled shapes and sizes to a surface or even the creation of nano- and micro-structured patterns (Figure 2A).

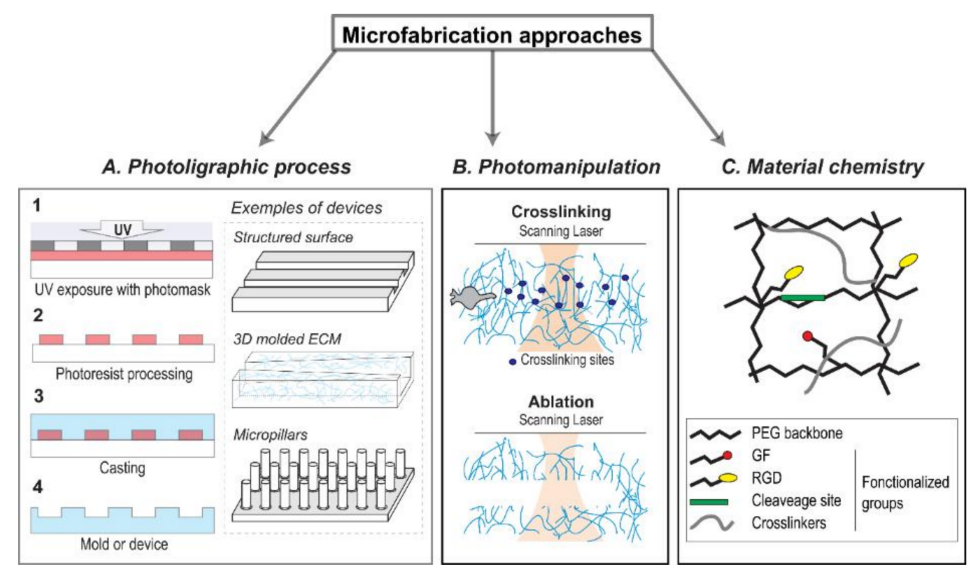

Figure 2. Illustration of different microfabrication approaches to mimic in vitro 3D microenvironment. Multiple methods, involving either natural or synthetic biomaterials, have been developed to engineer extracellular matrix (ECM) scaffolds and recapitulate the 3D physical features of the in vivo native ECM. (A) Simplified workflow for photolithography-based microfabrication where the first step is to inscribe the desired pattern present on a photomask in a photoresist. UV exposed photoresist can then be developed to obtain either a functional device or a negative mold that can then be used to cast a device from the desired material. This ubiquitous technique is routinely used to generate microstructured surfaces for cell adhesion, mold complex 3D scaffolds and microfluidic devices, or advanced active force sensors such as the micropillar systems. Furtermore, to increase collagen hydrogel stiffness used for cell culture and achieve stiffness levels closer to those found in tumor tissues, collagen can be crosslinked (B) by using enzymatic (i.e., LOX, TG2) and non-enzymatic (i.e., glycation) collagen crosslinking but also photoactivable crosslinkers (i.e., riboflavin). Alternatively, laser photo-ablation can be used to write microstructures within 3D hydrogels scaffolds. Synthetic biomaterials $(\mathbf{C})$, such as polyethylene glycol (PEG) hydrogel, are synthesized to incorporate different functional groups, e.g., the Arg-Gly-Asp (RGD) peptide sequences (cell binding sites) or MMP-sensitive peptides (MMP-degradable region) as part of their design. 
Using these systems, it was shown that cell contact surface area influences the cell cytoskeleton dynamic and mechanical properties $[49,51]$. The shape and geometry of the contact area also influence mechanical strain distribution within the cell $[49,52]$. Pushing this idea further, Kassianidou et al. generated a pattern that mimics the discrete distribution of ECM components seen in 3D on a 2D substrate and demonstrated that the initial position of the cell relative to the geometry of the available ECM regulates the actin fiber dynamic and organization, thus providing an "adhesion memory" to the cell [50,52]. Moreover, studies performed on several types of cancer cells showed that substrate stiffness and the inherent behavior of tumor cells are linked [11,17,29,53]. However, the TME mechanical properties display a large degree of spatial heterogeneities [54]. There is therefore a need to develop methods that allow the control of substrate. Work performed with engineered photosensitive materials have allowed researchers to generate substrates for which stiffness can be tuned in real time [55-58]. Interestingly, these substrates can allow fine spatial control of the substrate stiffness to study biological functions such as cell migration or cell fate [57,58]. Furthermore, several of these methods are flexible enough that they can be combined [58], enabling spatial and temporal control over substrate adhesion geometry and mechanical properties. These improvements are critical to achieve better in vitro tumor model design.

\subsection{D Substrate-Engineered Extracellular Matrix (ECM) Scaffolds}

Mimicking 3D microenvironment and ECM is one of the most challenging studies in order to explore the complexity of the in vivo system. Thus, it is really important to construct the closest 3D in vitro system to the native ECM [59]. The field of mechanobiology has focused on strategies involving either natural or synthetic biomaterials to attempt to recapitulate the 3D physical features of the in vivo environment (Figure 3).

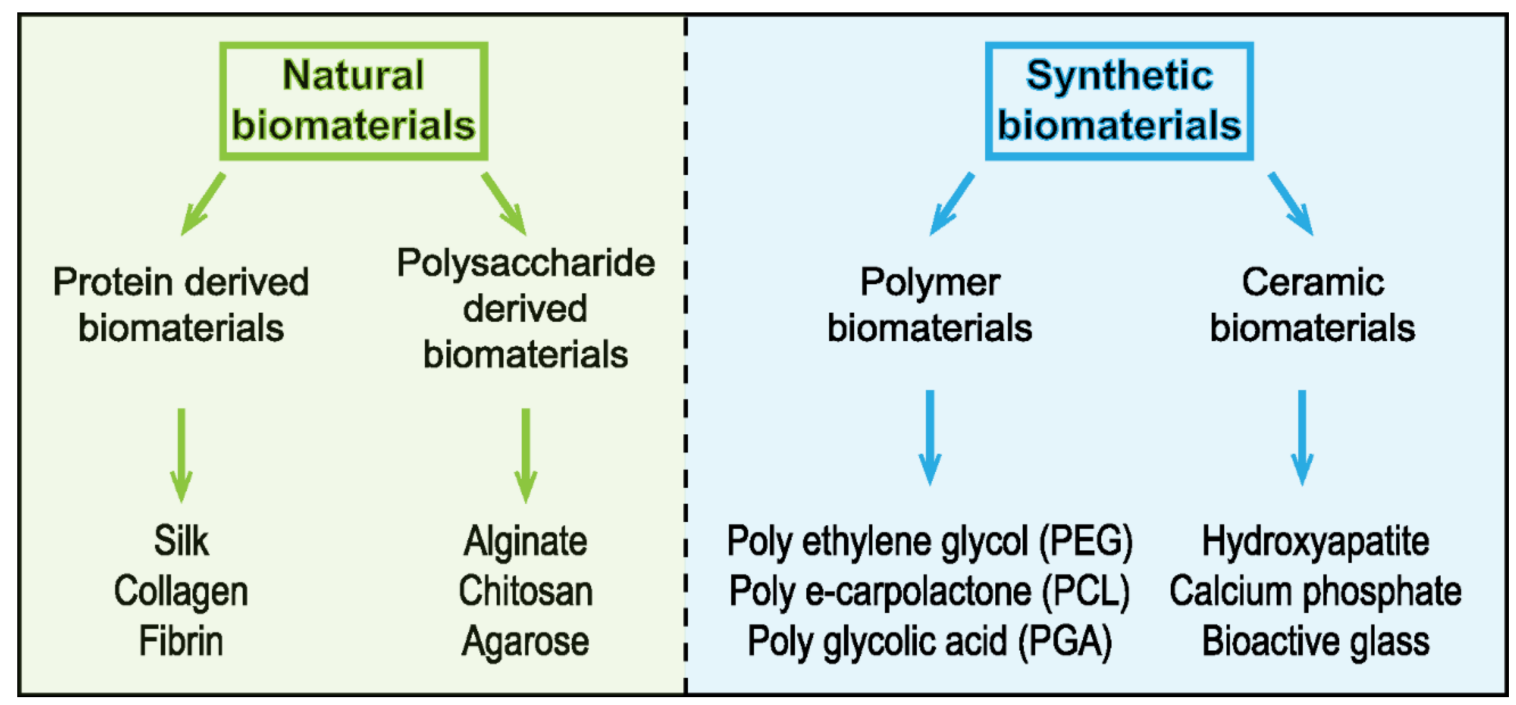

Figure 3. Classification of different biomaterials used as substrate for cell modeling.

Researchers have used physiologically relevant biomaterials such as collagen [46]. Notably, collagen is one of the most abundant proteins of the ECM and contributes to increased tumor stiffness [13]. Collagen is known to self-assemble into a fibrous network, and it is possible to control its organization to preferentially obtain long and aligned fibers or very densely packed short fibers [60-62]. Collagen 3D architecture and density are known to influence cell migration parameters, including cell speed and migration persistence [60]. However, the stiffness of the typical collagen hydrogels used for cell culture are usually significantly lower than the tissue or tumor they are intended to recapitulate, ranging from around $50 \mathrm{~Pa}$ at a concentration of $1 \mathrm{mg} / \mathrm{mL}$ to $1 \mathrm{kPa}$ at $10 \mathrm{mg} / \mathrm{mL}$ [12]. Strategies employed to overcome this technical issue have relied on using either enzymatic or non-enzymatic 
collagen crosslinking to achieve stiffness levels closer to those found in tumor tissues [63]. For example, non-enzymatic glycation can be used to crosslink collagen either in solution prior to polymerization or once the scaffold is established, thus providing a way to tune the stiffness of a collagen scaffold independently of its concentration and 3D architecture [64] (Table 1).

Table 1. Comparison of the biological scaffolds and synthetic scaffolds used for cell culture.

\begin{tabular}{|c|c|c|}
\hline Properties & Biological Scaffold & Synthetic Scaffold \\
\hline Degradability & Degradable with a long-time storage & Better storage stability \\
\hline Immunogenicity & $\begin{array}{l}\text { Poorly immunogenic Antigen content is } \\
\text { removed during decellularization }\end{array}$ & $\begin{array}{l}\text { Biocompatibility issue can trigger } \\
\text { inflammatory response }\end{array}$ \\
\hline Reproducibility & $\begin{array}{l}\text { Native architecture is highly preserved } \\
\text { (decellularized scaffolds) } \\
\text { Batch to batch variation }\end{array}$ & $\begin{array}{l}\text { Very complex architecture } \\
\text { High possibility of control }\end{array}$ \\
\hline Cell adhesion & Presence of native integrin sites & $\begin{array}{l}\text { Lack of specific integrin binding } \\
\text { site }\end{array}$ \\
\hline Biocompatibility & $\begin{array}{c}\text { Depends on the material: Good for } \\
\text { native ECM (e.g. collagen, fibrin, etc.) } \\
\text { Lower for exogenous biomaterials (e.g. } \\
\text { silk, alginate, etc.) }\end{array}$ & $\begin{array}{l}\text { Poor compatibility Cytotoxicity by } \\
\text { co-products of degradation }\end{array}$ \\
\hline
\end{tabular}

We and other groups have taken advantage of this approach as a way to model a tumor mechanical property to investigate the effects of 3D matrix stiffness-mediated angiogenesis, cancer cell contractility, and invasive properties $[28,65,66]$. Alternatively, photoactivable crosslinkers, such as riboflavin, can also be used to crosslink collagen $[67,68]$ (Figure 2B). While such an approach theoretically allows the stiffness of collagen or any 3D ECM-based scaffolds to be precisely and spatially tuned, it has not seen widespread use in the field. This is likely related to the phototoxicity induced by the blue and UV wavelength needed for the photocrosslinking process [69]. Another method for controlling stiffness is to use recombinant versions of the enzymes that are responsible for the crosslinking of collagen scaffolds in vivo. Indeed, both the LOX and TG2 (transglutaminase 2) enzyme have been used to stiffen collagen scaffolds [70,71]. Other materials have been used such as fibrin or matrigel depending on its characteristics and the cancer research applications. For example, matrigel, characterized by its cytocompatibility and its tunable properties, was used in breast cancer modeling and helped to understand the role of cell assembly and progression in the development of the disease [72].

Other biomaterials have been considered as 3D scaffolds, notably the Antheraea Mylitta fibroin protein, a silk protein generated from the tasar silkworm [73] This silk-derived scaffold was used as an ECM equivalent for an in vitro breast cancer model [74]. Silk fibroin demonstrates promising mechanical properties such as stiffness strength [75]. It is characterized by its biocompatibility, biodegradability, high versatility, and a porous structure ( $\sim 50-500 \mu \mathrm{m}$ pore size) [76]. Owing to its characteristics, silk fibroin fibers have been used in engineering and medicine. It is used as matrices for 3D cell culture, 3D microenvironment for cell attachment, growth, and co-culture for tumor cells [76]. The high porosity of the fiber plays an essential role in cell growth as it allows nutrient and waste exchanges [74]. Recently, it has been used in modeling different types of cancers, including hepatocarcinoma, osteosarcoma, breast, and prostate cancer $[73,77,78]$. Engineered scaffolds produced from natural biomaterials suffer from several intrinsic limitations, notably because of their heterogeneous and anisotropic nature [79]. In this context, synthetic biomaterials are increasingly used in biomedical research. The advantages of synthetic biomaterials include tunable chemistry, easy to control biomechanical properties, and biocompatibility and biodegradability [80-82]. Synthetic biomaterials can be synthesized to incorporate different functional groups within as part of their design, such as cell binding sites (e.g., the RGD peptide sequences) or the MMP-degradable regions (e.g., GGGPQGIWGQGK (PQ) peptide), resulting in physiologically relevant cell-matrix interactions [83] (Figure 2C). Use of polyethylene glycol (PEG) 
hydrogel-containing RGD and MMP-sensitive peptides have helped highlight the growth of epithelial ovarian cancer cells [84]. Notwithstanding that matrixes composed of synthetic polymers present some disadvantages such as cytotoxicity and lower degradability [85], synthetic polymers offer the highest levels of control over their tailored chemistry and overall physical properties.

\subsection{D Microfabricated Substrate}

To further control and design tunable 3D scaffolds, several groups have adopted molded microfabrication techniques based on cast PDMS (polydimethylsiloxane) or native ECM [86-88] (Table 2).

Table 2. Characteristics of the most widely used material for microfabrication device for cell biology applications.

\begin{tabular}{|c|c|c|}
\hline Devices & Advantages & Disadvantages \\
\hline PDMS based device & $\begin{array}{ll}\text { - } & \text { Ease of fabrication } \\
\text { - } & \text { Cheap } \\
\text { - } & \text { Tunable elasticity } \\
\text { - } & \text { Isotropic mechanical properties } \\
\text { - } & \text { Excellent material for mold-based } \\
\text { device manufacture } \\
\text { - } & \begin{array}{l}\text { Selective gas permeability is well } \\
\text { suited for microfluidic systems }\end{array}\end{array}$ & $\begin{array}{l}\text { - Modifications restricted to } \\
\text { surface properties } \\
\text { Possible range of stiffness in the } \\
\text { upper range of physiological values } \\
>5 \mathrm{kPa}\end{array}$ \\
\hline Collagen based device & $\begin{array}{l}\text { - } \quad \text { Physiological native ECM } \\
\text { - } \quad \text { Principal ECM component in several } \\
\text { type of tumors } \\
\text { - } \quad \text { Fibrillar architecture } \\
\text { - } \quad \text { 3D architecture is the most } \\
\text { representative of in vivo conditions }\end{array}$ & $\begin{array}{ll}\text { - } & \text { Costly } \\
\text { - } & \text { Hard to control heterogeneity } \\
\text { - } & \text { Stiffness and scaffold architecture are } \\
\text { - } & \text { hard to decouple } \\
\text { induce toxicity } \\
\text { - } \quad \text { Not suitable for all cell types } \\
\text { - } \quad \text { Higher stiffnesses are hard to achieve }\end{array}$ \\
\hline PEG based device & $\begin{array}{l}\text { - } \quad \text { Fully tunable chemistry } \\
\text { - } \quad \text { Precise control of desired } \\
\text { architecture and physical properties }\end{array}$ & $\begin{array}{ll}\text { - } & \text { Cytotoxicity } \\
\text { - } & \text { Low degradability } \\
\text { - } & \text { Isotropic physical properties not } \\
& \text { representative of in vivo }\end{array}$ \\
\hline
\end{tabular}

In brief, the fabrication technique uses a photolithography process to obtain a master mold that is then used to cast a device containing desirable features. The main goal is to replicate the architecture and features such as density, pore size, and fiber alignment that are observed within the tumor stroma [89]. Results showed that channels with limiting cross sections similar to the space found in vivo act as a limiter for efficient cell migration [90]. Interestingly, use of microfabricated constriction has highlighted a previously unknown mechanism: the nucleus can rupture and generate DNA break when tumor cells migrate through severely limiting constrictions, an outcome that was further confirmed in vivo [91]. Alternatively, approaches have been developed to better mimic in vivo physiological conditions, and microfabrication techniques were applied to several biomaterials, including native ECM, proteoglycans, or polysaccharides in the stroma microarchitecture. For instance, microtracks can be manufactured from 3D collagen scaffolds as a physiologically relevant mimic of the collagen structure found within in vivo tumors [92]. Alternatively, others have used laser photo-ablation to write microstructures within hydrogels $[93,94]$, which were subsequently used to study collective cell migration and MMP-independent tumor cell migration [95]. Combining some of the techniques that were originally designed as 2D system to generate 3D architecture was a great step toward obtaining better in vitro systems that more closely mimic in vivo conditions (Table 3). 
Table 3. Reproducing tumor microenvironment (TME) features in 2D versus 3D experimental models.

\begin{tabular}{|c|c|c|c|}
\hline \multirow[b]{2}{*}{ TME Features } & \multicolumn{2}{|c|}{ 2D Cell Culture } & \multirow[b]{2}{*}{ 3D Cell Culture } \\
\hline & $\begin{array}{c}\text { Traditional } \\
\text { (Glass/Plastic Dishes, } \\
\text { Plates) }\end{array}$ & $\begin{array}{l}\text { Microfabricated-Engineered } \\
\text { Substrate }\end{array}$ & \\
\hline Stiffness & $\begin{array}{l}\text { Non-physiological } \\
\text { High stiffness > } \\
\text { Mpa-Gpa }\end{array}$ & $\begin{array}{c}\text { Tunable over a } \\
\text { physiological range of } \\
\text { stiffness }\end{array}$ & $\begin{array}{c}\text { Tunable stiffness } \\
\text { High stiffness }(>5 \mathrm{kPa} \text { ) are difficult to } \\
\text { achieve using native ECM }\end{array}$ \\
\hline $\begin{array}{l}\text { Architecture and spatial } \\
\text { organization }\end{array}$ & Uniform flat surface & $\begin{array}{l}\text { Tunable surface features: } \\
\text { Spatial heterogeneities, } \\
\text { stiffness gradient }\end{array}$ & $\begin{array}{l}\text { Fully tunable features: } \\
\text { Heterogeneities, pore size, matrix } \\
\text { density, microarchitecture }\end{array}$ \\
\hline $\begin{array}{c}\text { Availability of small } \\
\text { molecules }\end{array}$ & Free distribution & Free distribution & $\begin{array}{c}\text { Material pore size can impede } \\
\text { diffusion; } \\
\text { Gradients of soluble factors, nutrients } \\
\text { and oxygen can form }\end{array}$ \\
\hline Cellular organization & $\begin{array}{l}\text { 2D geometry constrains } \\
\text { morphogenesis }\end{array}$ & $\begin{array}{l}\text { 2D geometry constrains } \\
\text { morphogenesis }\end{array}$ & Free to self-organize in 3D \\
\hline Accessibility & $\begin{array}{l}\text { Simplest method, cost } \\
\text { can scale with culture } \\
\text { conditions }\end{array}$ & $\begin{array}{l}\text { Added complexity } \\
\text { Fabrication process can } \\
\text { add cost }\end{array}$ & $\begin{array}{l}\text { Increased complexity } \\
\text { No standard methods } \\
\text { Limited by fabrication cost, ease of use } \\
\text { and compatible analytical assays }\end{array}$ \\
\hline $\begin{array}{l}\text { Ability to mimic the } \\
\text { TME }\end{array}$ & - & + & ++ \\
\hline
\end{tabular}

\subsection{Microfabrication for Force Measurement}

Fabricating an engineered TME is one step forward. However, the physical properties of the material used can directly influence cells. In fact, cellular response and adaptation to the physical environment is an active process, where cells continuously probe and exert force on their surrounding ECM. In turn, the ECM also provides active (traction, compression) or passive (stiffness, viscosity, plasticity) mechanical cues to the cells. While this interplay provides important cues that drive biological functions, such as cell migration and morphogenesis, it is entirely dependent on the generation of intracellular mechanical forces by the actomyosin contractile structures $[96,97]$. There are therefore increasing efforts being made in trying to implement force measurement as a part of microfabricated devices. By pushing the boundaries of microfabrication techniques, several groups have come up with strategies to manufacture devices that allow force measurements while mimicking the physical properties of the microenvironment as closely as possible. Microelectromechanical systems (MEMS) were developed to investigate cellular behaviors in the system, as well as MEMS sensors able to measure micronewton levels of forces or less while following the migration of a single cell. Many microdevices have been functionalized and tested to measure 3D cell forces, such as large cantilevers fabricated by soft lithography [98]. A mimetic tissue is capable of self-assembly between two cantilevers in a culture chamber. The deflection of the pillars over time allows fast and automated detection of the bulk contraction of the tissue [99]. An implementation of this system with multiple anchoring pillars was able to demonstrate how mechanical strain, cellular forces, and matrix assembly govern tissue repair and wound closure in a 3D system [100]. Another microdevice used to measure the forces generated by cells while migrating is the micropillar arrays, which consists of closely and evenly spaced elastic PDMS pillars that enable the measurement of the force based on its deflection [101,102]. By controlling the spatial distribution of the pillar shape and height, it is possible to generate substrate containing heterogeneous rigidity islands. Such a system can then be used to investigate the effect of mechanical heterogeneities on biological function such as endothelial barrier functions in a controlled and reproductive fashion [103]. In an effort to upgrade the design, asymmetric pillars were designed to provide different mechanical properties following the main pillar axis [104-106]. The micro-engineered pillars allowed the investigation of how anisotropic mechanical properties can provide migration cues and help steer the cells [105]. Different MEMS were developed and every microfabricated tool has its own characteristics based on the limit range of forces detected, the substrate and its stiffness, and the number of cells seeded to have a result. 


\section{Integrating Microfluidic Devices and Microfabrication to Generate Tumor Models}

While microfabrication methods allow increasingly accurate depiction of the TME, cell migration is not solely regulated by the ECM. Within tissues, soluble factors can generate gradients that induce polarization and guided cell migration chemotaxis [107]. This is particularly relevant during cancer metastasis where cell migration directly plays a major role. Microfluidic devices have long been used to study these mechanisms by simulating with precision soluble factor gradients $[108,109]$. Recent efforts have tried to couple these devices with what we have learned from microfabrication of the TME to produce integrated tumor on a chip-like system. Combined approaches provide control over a wide range of TME features, including soluble factors availability, oxygen levels, ECM architecture, and mechanical properties that have allowed inroad into a better understanding of the metastatic process $[110,111]$. In fact, several different pro-migratory cues and ECM features can all be combined within one device (Figure 4A).
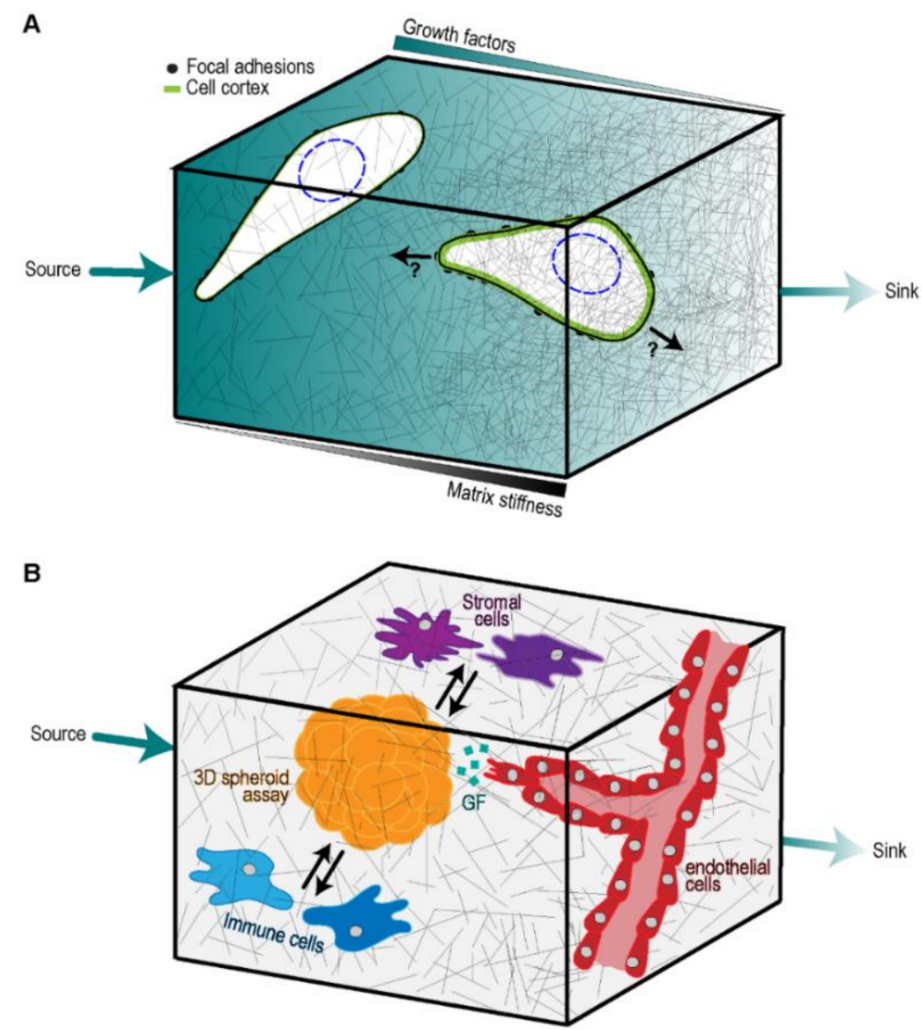

Figure 4. Coupling microfluidic devices with 3D microfabrication as a mimicking model of the TME chemical and physical features. (A) 3D microfabricated substrates presenting a matrix stiffness gradient can be coupled with microfluidic device to generate a growth factor gradient. The increase of matrix stiffness as well as GFs promote contractility and cellular migration. This method can be used for conflicting migration cues and determine for example if cell migration in this context is more dictated by chemotaxis or mechanotaxis. (B) More complete models mimicking the TME are possible by using co-cultured cells embedded in 3D microfabricated substrates. Co-cultured cells can combine tumor cell 3D spheroids, patient-derived organoids, endothelial cells, stromal cells such as fibroblasts or CAFs, and immune cells such as B lymphocytes. An intercellular crosstalk (black arrow) is established between the spheroid and the others cell types and is managed by direct cell-cell interactions and indirect communication through different components (e.g., chemokines, cytokines, growth factors). On the one hand, tumor cells secrete different factors, such as VEGF (green square), stimulating the sprouting of vascular endothelial cells. On the other hand, a growth factor gradient can be artificially created and finely controlled to induce a tumor dissemination-like process. 
State-of-the-art microfluidic approaches tend to recreate as accurately as possible the complexity of the ECM [112]. Several teams have come up with 3D systems that allow the formation of a precise soluble factor gradient such as oxygen [113], shear stress [114], or tumor-vascular secreted molecules [115]. Type I collagen hydrogel and Matrigel represent the standard 3D scaffolds used within current microfluidic devices [116,117]. Interestingly, tumor cell migration and phenotype are affected by the nature of the scaffold, where a mixture of both collagen and Matrigel allows the highest migration distance and speed [117]. In this study, the collagen and Matrigel mixture were found to be less permeable to the chemoattractant compared to collagen alone. Interestingly, the collagen and Matrigel mixture that allowed maximum migration speed was also stiffer than collagen alone [117]. Furthermore, this concept was extended to the presence of ECM density interfaces, where a growth factor gradient applied from the side of a low-density collagen interface gradient was more efficient in promoting chemotaxis than when applied from the high-density side [117]. More sophisticated than hydrogels, a fabrication method uses electrospun matrices to control the ECM architecture by electrospinning to erect organized polycaprolactone matrix layers. It also provides the possibility to change the matrix material and retrieve the post-experimental matrix [118]. The sophistication of the biomaterial and possible cellular effects requires state-of-the-art equipment in order to assess properly the studied cellular responses. The studies of ECM-dependent cell behavior highlight the importance of considering ECM cell migration properties in a complex environment.

Cell contractility is substrate-dependent, and inversely, cell responses to substrate depend on the contractility state of the cell. Cell contractility is driven by changes in cytoskeletal tensions induced by modifications in the extracellular environment. ECM mechanoproperties influence cell contractility, which in turn will affect cell migration, cell adhesion, and GF signal transduction [15]. Initial simple designs used cast PDMS devices to combine physical confinement with chemoattractant $[90,119]$. A microfluidic approach emerged using areas of high shear to induce the aggregation of platelets towards block posts, also referred to as force sensors. The contractile force engaged by platelets can be measured through the deflection of the post over time [120]. Furthermore, real time imaging is one of the main features constituting the future of microfluidic approaches. Quantitative polarization microscopy (QPOL) is a new imaging method that can assess and measure cell contractility through cytoskeleton mechanic state at subcellular level. The power of this innovative microscopy is represented by the possible observable range from single cell and 2D monolayer to 3D complex biological samples [28]. Microfluidic devices coupled with a quantitative polarization microscopy (QPOL) in real time could represent a promising association. It could ameliorate the study of cell contractility modulations across different conditions monitored in microfluidic devices such as ECM stiffness, shear stress, and GF gradients.

The role of TME non-malignant cells is significant in tumorigenesis, notably in cell migration. Results have shown cancer cells and stroma cells can increase migration speed, reciprocally acting towards enhancing symbiosis [121]. Interestingly, combining CAFs tumor cells and 3D collagen in a microfluidic chamber resulted in a synergistic amplification of the angiogenic response of endothelial cells, which was not observed when each component was used individually [122]. In a more complex tissue sample, associated tumor spheroids and fibroblast-like cells showed enhanced cytoskeletal tension, epithelial-mesenchymal transition (EMT) biological features, cell motility, spheroid number, and size in a 3D co-culturing microfluidic device [123,124]. Overall, the interaction between tumor cells and stroma cells are essential for tumorigenesis. Replicating these interactions with more complete tumor engineered models will be key to making further inroads into understanding the molecular regulators of metastatic processes (Figure 4B). An interesting technology that could help in increasing the fidelity and lowering the cost of engineered models is the use of bioprinting methods. Most bioprinting approaches use extrusion-based hydrogels that produce large mm scale features $[125,126]$. However, laser-assisted bioprinting (LAB) is an emerging and promising bioprinting tool that has the potential to achieve the resolution required to produce an engineered TME. Indeed, this technique is already utilized to bioprint large sized vessels [127]. Interestingly, current laser bioprinters have a maximum 
resolution of $20 \mu \mathrm{m}$, which is within the range of possible bioprinting biological entities [126]. Therefore, while still beyond the current systems, this technology could eventually enable the production of small features such small diameter vessels $(\leq 5 \mu \mathrm{m})$ and capillaries $(3 \mu \mathrm{m})$ [128,129], two desirable features in an integrated microfluidic system that are essential to push artificial TME modeling forward.

The major concern in antitumor drug treatment is drug resistance. Microfluidic devices already provide precious help to overcome this problem [130]. Recent investigations have used high throughput screening in microfluidic devices directly with tumor biopsies in order to develop patient specific treatments [131]. A different approach instead combines a multilayered chamber architecture and 3D cell culture to perform combinatory drug screening, with a proof of concept using two standards of care drugs (doxorubicin and paclitaxel) with up to 64 different drug combinations, showcasing the multiplexing ability of this microfluidic system [132]. A future direction will be to see if targeting the ECM physical property can synergize other drug treatments, and microfluidic devices are likely to provide the means to test this possibility. Indeed, there is clinical interest in targeting the ECM. Some drugs indirectly target the ECM, such as anti-CTLA4 (cytotoxic T-lymphocyte-associated protein 4) antibody treatment, which activates immune response $[33,133]$. Several preclinical drug approaches targeting myeloid cell response to inflammatory cytokines influence MMPs activity and downregulate TGF $\beta$ [134], thereby indirectly affecting ECM remodeling within the tumor. Another drug study directly targeted the ECM architecture using specific ECM-destroying enzymes, increasing the permeability of the system so that antitumor treatments can more easily diffuse through the actual tumor for added efficiency [135]. This is an interesting approach as drug delivery within a tumor is indeed a clinical issue [136]. In the light of these results, the success rate of anti-tumor treatments in patients could get better, coupled with in vivo mimicking microfluidic approaches with an improved drug screening. These engineered tissue devices could be used in pre-clinical tests for different cancer subtypes providing critical data to the medical field. Furthermore, the combination of tissue-engineered models and drug screening provides important data about the underlying mechanisms of drug resistance.

The heterogeneity of the cell population present within the tumor provides quite a challenge. The tumor cell population as a whole might not respond to a given treatment as a homogenous population. Here, the flexibility of microfluidic devices brings some interesting possibilities that allow high throughput single cell assays. Indeed, single-cell studies are essential to understand tumor heterogeneity as cancer cells represent a complex group of different cell subpopulations with different properties [137]. Studying tumor cell heterogeneity within the context of the TME at the single cell level with traditional tools is very challenging, while combining single cell analysis with adapted microfluidic devices provides promising results [138,139]. Different methods have been developed in order to undergo single cell analysis based on the combination of optical, magnetic, electrical, and microfluidic approaches [140-142]. However, the isolation process removes the environmental contribution from the system. Recently, single-cell co-culture microfluidic methods have been developed to address this issue by including chambers that provide control over the cell-environment interaction at the single cell level. One such device was used to study different cell sub-population paracrine interactions with a single cell trap with pores that allow paracrine signal to diffuse from a tumor cell population kept in a chamber underneath [143]. Alternatively, a high throughput microfluidic cell pairing device allows the investigation of behaviors of a heterogeneous immune cell population towards different microenvironment conditions via one-to-one cell pairings [144]. Both previous microfluidic devices permit the retrieval of studied cells for single-cell level genomic analysis. These high throughput approaches open the possibility of performing single cell studies within a TME context, thus helping in deciphering the underlying biology and potentially enabling drug screening strategies at a lower cost for pharmacy companies $[143,144]$. Furthermore, the trapping chamber concept can be expanded to larger components, such as spheroids. In this particular case, one chamber can have a trapped single cell that will grow into a tumor spheroid while a concomitant chamber can contain a stromal cell such as activated fibroblast [145]. Overall, these approaches could in fact allow the different contribution of individual components of the TME to be picked apart to better understand how tumor 
heterogeneity drives cellular behavior and genetic expression. Our ability to combine these with other single cell techniques, including force measurements and use of advance molecular imaging techniques, to overcome 3D scaffold limitations are key to moving forward.

\section{Conclusions and Perspectives}

Traditional in vitro tumor models have long suffered from oversimplification, mainly due to the use of non-physiological substrate with conditions that do not match the disease. Animal models come with their own limitations, either stemming from the difference in the underlying biology of a mouse, or the lack of control over the experimental conditions. Strategies that came from the field of engineering have opened several new lines of investigation. One of the major advantages is the increased control one has over all the possible variables and parameters required in the model. Still, some limitations remain as it is often challenging to perform mechanistic cellular assays within an enclosed, 3D mechanically stable sealed device. Indeed, the ability to combine such a device with proteomics, genomics, and biochemistry will further help in achieving the full potential of these device-based disease models.

Nevertheless, having access to a more accurate tumor model is certainly an obvious gain for the field. The added complexity provided by in vitro 3D multicellular TME engineered models provides a novel paradigm on which to base our search for improved therapeutics. An important issue that can be addressed is the overall lack of therapeutic target for TMEs, with most drugs currently considered in clinical trial having a severe off target effect given the ubiquitous nature of ECM components [10]. Moreover, since the patient-specific nature of tumors gives rise to a wide distribution of possible mechanical properties, our ability to provide a matching model will certainly lead to improved personalized medicine. Providing an environment that closely mimics the TME makes it more likely that cells will respond in a way that matches their in vivo state. Overall, equipped with enabling models of the tumor condition, research in the field will be able to tackle previously inconceivable mechanisms, ranging from the onset of the disease to terminal metastasis. This will indeed bring an interdisciplinary outlook that will drive research effort, and toward novel clinical targets. The progress made over the last decade has built a strong mechanobiology knowledge base that provides a clear way forward to investigate the importance of the microenvironment during disease progression. Future applications will likely combine multiple approaches, such as microfluidic and force sensors, within the same device. As the field transitions toward more complete and higher throughput TME engineered models, we can expect a big leap in our understanding of tumor biology and drug development from a mechanobiology perspective. These new TME engineered models are likely to become an established high throughput platform for pre-clinical study in the future.

Author Contributions: Writing—original draft preparation, M.M. and R.B.M; writing—review and editing, M.M., R.B.M., C.L., and F.B; supervision, F.B.

Acknowledgments: This work was supported by a Scholarship for the Next Generation of Scientists from the Cancer Research Society, a Junior I salary award and an establishment grant from the fond de recherche du Québec - Santé (FRQS) to Francois Bordeleau.

Conflicts of Interest: The authors declare no competing interests.

\section{References}

1. Stroock, A.D.; Fischbach, C. Microfluidic culture models of tumor angiogenesis. Tissue Eng. 2010, 16, 2143-2146. [CrossRef] [PubMed]

2. Yamada, K.M.; Cukierman, E. Modeling tissue morphogenesis and cancer in 3D. Cell 2007, 130, 601-610. [CrossRef] [PubMed]

3. Ghajar, C.M.; Bissell, M.J. Tumor engineering: The other face of tissue engineering. Tissue Eng. 2010, 16, 2153-2156. [CrossRef] [PubMed] 
4. Derda, R.; Laromaine, A.; Mammoto, A.; Tang, S.K.Y.; Mammoto, T.; Ingber, D.E.; Whitesides, G.M. Paper-supported 3D cell culture for tissue-based bioassays. Proc. Natl. Acad. Sci. USA 2009, 106, 18457-18462. [CrossRef] [PubMed]

5. Ghajar, C.M.; Suresh, V.; Peyton, S.R.; Raub, C.B.; Meyskens, F.L.; George, S.C.; Putnam, A.J. A novel three-dimensional model to quantify metastatic melanoma invasion. Mol. Cancer Ther. 2007, 6, 552-561. [CrossRef]

6. Han, W.; Chen, S.; Yuan, W.; Fan, Q.; Tian, J.; Wang, X.; Chen, L.; Zhang, X.; Wei, W.; Liu, R.; et al. Oriented collagen fibers direct tumor cell intravasation. Proc. Natl. Acad. Sci. USA 2016, 113, 11208-11213. [CrossRef]

7. Yu, F.; Hunziker, W.; Choudhury, D. Engineering microfluidic organoid-on-a-chip platforms. Micromachines 2019, 10, 165. [CrossRef]

8. Wang, M.; Zhao, J.; Zhang, L.; Lian, Y.; Wu, Y.; Gong, Z.; Zhang, S.; Zhou, J.; Cao, K.; Li, X.; et al. Role of tumor microenvironment in tumorigenesis. J. Cancer 2017, 8, 761-773. [CrossRef]

9. Janmey, P.A.; Miller, R.T. Mechanisms of mechanical signaling in development and disease. J. Cell Sci. 2011, 124, 9-18. [CrossRef]

10. Lampi, M.C.; Reinhart-King, C.A. Targeting extracellular matrix stiffness to attenuate disease: From molecular mechanisms to clinical trials. Sci. Transl. Med. 2018, 10, eaao0475. [CrossRef]

11. Levental, K.R.; Yu, H.; Kass, L.; Lakins, J.N.; Egeblad, M.; Erler, J.T.; Fong, S.F.T.T.; Csiszar, K.; Giaccia, A.; Weninger, W.; et al. Matrix crosslinking forces tumor progression by enhancing integrin signaling. Cell 2009, 139, 891-906. [CrossRef] [PubMed]

12. Bordeleau, F.; Mason, B.N.; Lollis, E.M.; Mazzola, M.; Zanotelli, M.R.; Somasegar, S.; Califano, J.P.; Montague, C.; LaValley, D.J.; Huynh, J.; et al. Matrix stiffening promotes a tumor vasculature phenotype. Proc. Natl. Acad. Sci. USA 2017, 114, 492-497. [CrossRef] [PubMed]

13. Gkretsi, V.; Stylianopoulos, T. Cell adhesion and matrix stiffness: Coordinating cancer cell invasion and metastasis. Front. Oncol. 2018, 8, 145. [CrossRef] [PubMed]

14. Hanahan, D.; Weinberg, R.A. Leading edge review hallmarks of cancer: The next generation. Cell 2011, 144, 646-674. [CrossRef] [PubMed]

15. Malik, R.; Lelkes, P.I.; Cukierman, E. Biomechanical and biochemical remodeling of stromal extracellular matrix in cancer. Trends Biotechnol. 2015, 33, 230-236. [CrossRef] [PubMed]

16. Balkwill, F.R.; Capasso, M.; Hagemann, T. The tumor microenvironment at a glance. J. Cell Sci. 2012, 125, 5591-5596. [CrossRef]

17. Paszek, M.J.; Zahir, N.; Johnson, K.R.; Lakins, J.N.; Rozenberg, G.I.; Gefen, A.; Reinhart-King, C.A.; Margulies, S.S.; Dembo, M.; Boettiger, D.; et al. Tensional homeostasis and the malignant phenotype. Cancer Cell 2005, 8, 241-254. [CrossRef]

18. Kai, F.; Laklai, H.; Weaver, V.M. Force matters: Biomechanical regulation of cell invasion and migration in disease. Trends Cell Biol. 2016, 26, 486-497. [CrossRef]

19. Gkretsi, V.; Stylianou, A.; Papageorgis, P.; Polydorou, C.; Stylianopoulos, T. Remodeling components of the tumor microenvironment to enhance cancer therapy. Front. Oncol. 2015, 5. [CrossRef]

20. Stupack, D.G. The biology of integrins. Oncology 2007, 21, 6.

21. Stupack, D.G. Integrins as a distinct subtype of dependence receptors. Cell Death Differ. 2005, 12, 1021-1030. [CrossRef] [PubMed]

22. Broders-Bondon, F.; Ho-Bouldoires, T.H.N.; Fernandez-Sanchez, M.-E.; Farge, E. Mechanotransduction in tumor progression: The dark side of the force. J. Cell Biol. 2018, 217, 1571-1587. [CrossRef] [PubMed]

23. Wang, W.; Lollis, E.M.; Bordeleau, F.; Reinhart-King, C.A.; Engineering, B. Matrix stiffness regulates vascular integrity through focal adhesion kinase activity. FASEB J. 2019, 33, 1199-1208. [CrossRef] [PubMed]

24. Bianconi, D.; Unseld, M.; Prager, G.W. Integrins in the spotlight of cancer. Mol. Sci. 2016, 17, 2037. [CrossRef] [PubMed]

25. Provenzano, P.P.; Inman, D.R.; Eliceiri, K.W.; Keely, P.J. Matrix density-induced mechanoregulation of breast cell phenotype, signaling, and gene expression through a FAK-ERK linkage HHS public access. Oncogene 2009, 28, 4326-4343. [CrossRef] [PubMed]

26. Salmerón-Sánchez, M.; Dalby, M.J.; Salmeró, N.-S.; Nchez, M. Synergistic growth factor microenvironments. Chem. Commun. 2016, 52, 13313-13420.

27. Grivennikov, S.I.; Greten, F.R.; Karin, M. Immunity, inflammation, and cancer. Cell 2009, 140, 883-899. [CrossRef] 
28. Wang, W.; Miller, J.P.; Pannullo, S.C.; Reinhart-King, C.A.; Bordeleau, F. Quantitative assessment of cell contractility using polarized light microscopy. J. Biophotonics 2018, 11, e201800008. [CrossRef]

29. Kraning-Rush, C.M.; Califano, J.P.; Reinhart-King, C.A. Cellular traction stresses increase with increasing metastatic potential. PLoS ONE 2012, 7, 32572. [CrossRef]

30. Knuchel, S.; Anderle, P.; Werfelli, P.; Diamantis, E.; Rüegg, C. Fibroblast surface-associated FGF-2 promotes contact-dependent colorectal cancer cell migration and invasion through FGFR-SRC signaling and integrin $\alpha$ v $\beta$ 5-mediated adhesion. Oncotarget 2015, 6, 14300. [CrossRef]

31. LaValley, D.J.; Zanotelli, M.R.; Bordeleau, F.; Wang, W.; Schwager, S.C.; Reinhart-King, C.A. Matrix stiffness enhances VEGFR-2 internalization, signaling, and proliferation in endothelial cells. Converg. Sci. Phys. Oncol. 2017, 3, 044001. [CrossRef] [PubMed]

32. Hinz, B. The extracellular matrix and transforming growth factor- $\beta 1$ : Tale of a strained relationship. Matrix Biol. 2015, 47, 54-65. [CrossRef] [PubMed]

33. Carmeliet, P.; Jain, R.K. Molecular mechanisms and clinical applications of angiogenesis. Nature 2011, 473, 298-307. [CrossRef] [PubMed]

34. Armulik, A.; Genové, G.; Betsholtz,C. Pericytes: Developmental, physiological, and pathological perspectives, problems, and promises. Dev. Cell 2011, 21, 193-215. [CrossRef] [PubMed]

35. Alitalo, K. The lymphatic vasculature in disease. Nat. Med. 2011, 17, 1371-1380. [CrossRef] [PubMed]

36. Metelitsa, L.S.; Wu, H.-W.; Wang, H.; Yang, Y.; Warsi, Z.; Asgharzadeh, S.; Groshen, S.; Wilson, S.B.; Seeger, R.C. Natural killer T cells infiltrate neuroblastomas expressing the chemokine CCL2. J. Exp. Med. J. Exp. Med. 2004, 199, 1213-1221. [CrossRef]

37. Campbell, D.J.; Koch, M.A.; Org, C. Phenotypic and functional specialization of FOXP3 + regulatory T cells. Nat. Rev. Immunol. 2011, 11, 119-130. [CrossRef]

38. Mauri, C.; Bosma, A. Immune regulatory function of B cells. Annu. Rev. Immunol. 2012, 30, $221-241$. [CrossRef]

39. Sinha, P.; Clements, V.K.; Bunt, S.K.; Albelda, S.M.; Ostrand-Rosenberg, S. Cross-talk between myeloid-derived suppressor cells and macrophages subverts tumor immunity toward a type 2 response. J. Immunol. 2007, 179, 977-983. [CrossRef]

40. Fernández-Riejos, P.; Goberna, R.; Sánchez-Margalet, V. Leptin promotes cell survival and activates Jurkat T lymphocytes by stimulation of mitogen-activated protein kinase. Clin. Exp. Immunol. 2008, 151, 505-518. [CrossRef]

41. Mancuso, P. The role of adipokines in chronic inflammation. ImmunoTargets Ther. 2016, 5, 47-56. [CrossRef] [PubMed]

42. Harjes, U.; Kalucka, J.; Carmuliet, P. Targeting fatty acid metabolism in cancer and endothelial cells. Oncol. Hematol. 2015, 97, 15-21. [CrossRef] [PubMed]

43. Valcz, G.; Szállási, Z.; Kalmár, A.; Krenács, T.; Tulassay, Z.; Igaz, P.; Molnár, B. Perspective: Bidirectional exosomal transport between cancer stem cells and their fibroblast-rich microenvironment during metastasis formation. Nat. Partn. J. 2018, 4, 18. [CrossRef] [PubMed]

44. Schwager, S.C.; Bordeleau, F.; Zhang, J.; Antonyak, M.A.; Cerione, R.A.; Reinhart-King, C.A. Matrix stiffness regulates microvesicle-induced fibroblast activation. Cell Physiol. 2019, 615-875. [CrossRef] [PubMed]

45. Unger, C.; Kramer, N.; Walzl, A.; Scherzer, M.; Hengstschläger, M.; Dolznig, H. Modeling human carcinomas: Physiologically relevant 3D models to improve anti-cancer drug development. Adv. Drug Deliv. Rev. 2014, 79, 50-67. [CrossRef] [PubMed]

46. Alemany-Ribes, M.; Semino, C.E. Bioengineering 3D environments for cancer models. Adv. Drug Deliv. Rev. 2014, 79, 40-49. [CrossRef] [PubMed]

47. Cooke, M.J.; Phillips, S.R.; Shah, D.S.H.; Athey, D.; Lakey, J.H.; Przyborski, S.A. Enhanced cell attachment using a novel cell culture surface presenting functional domains from extracellular matrix proteins. Cytotechnology 2008, 56, 71-79. [CrossRef]

48. Thery, M. Micropatterning as a tool to decipher cell morphogenesis and functions. J. Cell Sci. 2010, 123, 4201-4213. [CrossRef]

49. Mandal, K.; Asnacios, A.; Goud, B.; Manneville, J.-B. Mapping intracellular mechanics on micropatterned substrates. Proc. Natl. Acad. Sci. USA 2016, 113, E7159-E7168. [CrossRef] 
50. Kassianidou, E.; Probst, D.; Jäger, J.; Lee, S.; Roguet, A.L.; Schwarz, U.S.; Kumar, S. Extracellular matrix geometry and initial adhesive position determine stress fiber network organization during cell spreading. Cell Rep. 2019, 27, 1897-1909. [CrossRef]

51. Guo, M.; Pegoraro, A.F.; Mao, A.; Zhou, E.H.; Arany, P.R.; Han, Y.; Burnette, D.T.; Jensen, M.H.; Kasza, K.E.; Moore, J.R.; et al. Cell volume change through water efflux impacts cell stiffness and stem cell fate. Proc. Natl. Acad. Sci. USA 2017, 114, E8618-E8627. [CrossRef]

52. Kassianidou, E.; Brand, C.A.; Schwarz, U.S.; Kumar, S. Geometry and network connectivity govern the mechanics of stress fibers. Proc. Natl. Acad. Sci. USA 2017, 114, 2622-2627. [CrossRef] [PubMed]

53. Dufort, C.C.; Paszek, M.J.; Weaver, V.M. Balancing forces: Architectural control of mechanotransduction. Nat. Rev. Mol. Cell Biol. 2011, 12, 308-319. [CrossRef] [PubMed]

54. Malandrino, A.; Mak, M.; Kamm, R.D.; Moeendarbary, E. Complex mechanics of the heterogeneous extracellular matrix in cancer. Extrem. Mech. Lett. 2018, 21, 25-34. [CrossRef] [PubMed]

55. Guvendiren, M.; Burdick, J.A. Stiffening hydrogels to probe short- and long-term cellular responses to dynamic mechanics. Nat. Commun. 2012, 3, 792. [CrossRef]

56. Yeh, Y.C.; Corbin, E.A.; Caliari, S.R.; Ouyang, L.; Vega, S.L.; Truitt, R.; Han, L.; Margulies, K.B.; Burdick, J.A. Mechanically dynamic PDMS substrates to investigate changing cell environments. Biomaterials 2017, 145, 23-32. [CrossRef]

57. Yang, C.; DelRio, F.W.; Ma, H.; Killaars, A.R.; Basta, L.P.; Kyburz, K.A.; Anseth, K.S. Spatially patterned matrix elasticity directs stem cell fate. Proc. Natl. Acad. Sci. USA 2016, 113, E4439-E4445. [CrossRef]

58. Kamimura, M.; Sugawara, M.; Yamamoto, S.; Yamaguchi, K.; Nakanishi, J. Dynamic control of cell adhesion on a stiffness-tunable substrate for analyzing the mechanobiology of collective cell migration. Biomater. Sci. 2016, 4, 933-937. [CrossRef]

59. Song, K.; Wang, Z.; Liu, R.; Chen, G.; Liu, L. Microfabrication-based three-dimensional (3-D) extracellular matrix microenvironments for cancer and other diseases. Int. J. Mol. Sci. 2018, 19, 935. [CrossRef]

60. Velez, D.O.; Tsui, B.; Goshia, T.; Chute, C.L.; Han, A.; Carter, H.; Fraley, S.I. 3D collagen architecture induces a conserved migratory and transcriptional response linked to vasculogenic mimicry. Nat. Commun. 2017, 8 , 1651. [CrossRef]

61. Carey, S.P.; Kraning-Rush, C.M.; Williams, R.M.; Reinhart-King, C.A. Biophysical control of invasive tumor cell behavior by extracellular matrix microarchitecture. Biomaterials 2012, 33, 4157-4165. [CrossRef] [PubMed]

62. Carey, S.P.; Goldblatt, Z.E.; Martin, K.E.; Romero, B.; Williams, R.M.; Reinhart-King, C.A. Local extracellular matrix alignment directs cellular protrusion dynamics and migration through Rac1 and FAK. Integr. Biol. 2016, 8, 821-835. [CrossRef] [PubMed]

63. Hapach, L.A.; Vanderburgh, J.A.; Miller, J.P.; Reinhart-King, C.A. Manipulation of in vitro collagen matrix architecture for scaffolds of improved physiological relevance. Phys. Biol. 2015, 12, 061002. [CrossRef] [PubMed]

64. Mason, B.N.; Reinhart-King, C.A. Controlling the mechanical properties of three-dimensional matrices via non-enzymatic collagen glycation. Organogenesis 2013, 9, 70-75. [CrossRef]

65. Suh, Y.J.; Hall, M.S.; Huang, Y.L.; Moon, S.Y.; Song, W.; Ma, M.; Bonassar, L.J.; Segall, J.E.; Wu, M. Glycation of collagen matrices promotes breast tumor cell invasion. Integr. Biol. 2019, 11, 1-9. [CrossRef]

66. Bordeleau, F.; Reinhart-King, C.A. Tuning cell migration: Contractility as an integrator of intracellular signals from multiple cues. F1000Research 2016, 5, 1819. [CrossRef]

67. Kwok, S.J.J.; Kuznetsov, I.A.; Kim, M.; Choi, M.; Scarcelli, G.; Yun, S.H. Selective two-photon collagen crosslinking in situ measured by Brillouin microscopy. Optica 2016, 3, 469. [CrossRef]

68. Kuetemeyer, K.; Kensah, G.; Heidrich, M.; Meyer, H.; Martin, U.; Gruh, I.; Heisterkamp, A. Two-photon induced collagen cross-linking in bioartificial cardiac tissue. Opt. Express 2011, 19, 15996. [CrossRef]

69. Vashi, A.V.; Werkmeister, J.A.; Vuocolo, T.; Elvin, C.M.; Ramshaw, J.A.M. Stabilization of collagen tissues by photocrosslinking. J. Biomed. Mater. Res. Part A 2012, 100, 2239-2243. [CrossRef]

70. Santhanam, L.; Tuday, E.C.; Webb, A.K.; Dowzicky, P.; Kim, J.H.; Oh, Y.J.; Sikka, G.; Kuo, M.; Halushka, M.K.; MacGregor, A.M.; et al. Decreased S-nitrosylation of tissue transglutaminase contributes to age-related increases in vascular stiffness. Circ. Res. 2010, 107, 117-125. [CrossRef]

71. Agnihotri, N.; Mehta, K. Transglutaminase-2: Evolution from pedestrian protein to a promising therapeutic target. Amino Acids 2017, 49, 425-439. [CrossRef] [PubMed] 
72. Carvalho, M.R.; Lima, D.; Reis, R.L.; Correlo, V.M.; Oliveira, J.M. Evaluating biomaterial- and microfluidic-based 3D tumor models. Trends Biotechnol. 2015, 33, 667-678. [CrossRef] [PubMed]

73. Talukdar, S.; Mandal, M.; Hutmacher, D.W.; Russell, P.J.; Soekmadji, C.; Kundu, S.C. Engineered silk fibroin protein 3D matrices for in vitro tumor model. Biomaterials 2011, 32, 2149-2159. [CrossRef] [PubMed]

74. Jastrzebska, K.; Kucharczyk, K.; Florczak, A.; Dondajewska, E.; Mackiewicz, A.; Dams-Kozlowska, H. Silk as an innovative biomaterial for cancer therapy. Rep. Pract. Oncol. Radiother. 2014, 20, 87-98. [CrossRef] [PubMed]

75. Qi, Y.; Wang, H.; Wei, K.; Yang, Y.; Zheng, R.Y.; Kim, I.S.; Zhang, K.Q. A review of structure construction of silk fibroin biomaterials from single structures to multi-level structures. Int. J. Mol. Sci. 2017, 18, 237. [CrossRef] [PubMed]

76. Dondajewska, E.; Juzwa, W.; Mackiewicz, A.; Dams-Kozlowska, H. Heterotypic breast cancer model based on a silk fibroin scaffold to study the tumor microenvironment. Oncotarget 2017, 9, 4935-4950. [CrossRef] [PubMed]

77. Kundu, B.; Saha, P.; Datta, K.; Kundu, S.C. A silk fibroin based hepatocarcinoma model and the assessment of the drug response in hyaluronan-binding protein 1 overexpressed HepG2 cells. Biomaterials 2013, 34, 9462-9474. [CrossRef] [PubMed]

78. Tan, P.H.S.; Aung, K.Z.; Toh, S.L.; Goh, J.C.H.; Nathan, S.S. Three-dimensional porous silk tumor constructs in the approximation of in vivo osteosarcoma physiology. Biomaterials 2011, 32, 6131-6137. [CrossRef]

79. Gu, L.; Mooney, D.J. Biomaterials and emerging anticancer therapeutics: Engineering the microenvironment. Nat. Rev. Cancer 2016, 16, 56-66. [CrossRef]

80. Alaribe, F.N.; Manoto, S.L.; Motaung, S.C.K.M. Scaffolds from biomaterials: Advantages and limitations in bone and tissue engineering. Biologia 2016, 71, 353-366. [CrossRef]

81. Fernandes, H.; Mentink, A.; Bank, R.; Stoop, R.; Van Blitterswijk, C.; De Boer, J. Endogenous collagen influences differentiation of human multipotent mesenchymal stromal cells. Tissue Eng. Part A 2009, 16, 1693-1702. [CrossRef] [PubMed]

82. Souza, G.R.; Molina, J.R.; Raphael, R.M.; Ozawa, M.G.; Stark, D.J.; Levin, C.S.; Bronk, L.F.; Ananta, J.S.; Mandelin, J.; Georgescu, M.M.; et al. Three-dimensional tissue culture based on magnetic cell levitation. Nat. Nanotechnol. 2010, 5, 291-296. [CrossRef] [PubMed]

83. Liu, Z.; Vunjak-Novakovic, G. Modeling tumor microenvironments using custom-designed biomaterial scaffolds. Curr. Opin. Chem. Eng. 2016, 11, 94-105. [CrossRef] [PubMed]

84. Loessner, D.; Stok, K.S.; Lutolf, M.P.; Hutmacher, D.W.; Clements, J.A.; Rizzi, S.C. Bioengineered 3D platform to explore cell-ECM interactions and drug resistance of epithelial ovarian cancer cells. Biomaterials 2010, 31, 8494-8506. [CrossRef] [PubMed]

85. Belgodere, J.A.; King, C.T.; Bursavich, J.B.; Burow, M.B.; Martin, E.C.; Jung, J.P. Engineering breast cancer microenvironments and 3D bioprinting. Front. Bioeng. Biotechnol. 2018, 6, 66. [CrossRef] [PubMed]

86. Yanagawa, F.; Sugiura, S.; Kanamori, T. Hydrogel microfabrication technology toward three dimensional tissue engineering. Regen. Ther. 2016, 3, 45-57. [CrossRef]

87. Annabi, N.; Nichol, J.W.; Zhong, X.; Ji, C.; Koshy, S.; Khademhosseini, A.; Dehghani, F. Controlling the porosity and microarchitecture of hydrogels for tissue engineering. Tissue Eng. Part B Rev. 2010, 16, 371-383. [CrossRef] [PubMed]

88. Golden, A.P.; Tien, J. Fabrication of microfluidic hydrogels using molded gelatin as a sacrificial element. Lab Chip 2007, 7, 720-725. [CrossRef]

89. Wolf, K.; te Lindert, M.; Krause, M.; Alexander, S.; te Riet, J.; Willis, A.L.; Hoffman, R.M.; Figdor, C.G.; Weiss, S.J.; Friedl, P. Physical limits of cell migration: Control by ECM space and nuclear deformation and tuning by proteolysis and traction force. J. Cell Biol. 2013, 201, 1069-1084. [CrossRef]

90. Paul, C.D.; Hung, W.-C.; Wirtz, D.; Konstantopoulos, K. Engineered models of confined cell migration. Annu. Rev. Biomed. Eng. 2016, 18, 159-180. [CrossRef]

91. Denais, C.M.; Gilbert, R.M.; Isermann, P.; McGregor, A.L.; te Lindert, M.; Weigelin, B.; Davidson, P.M.; Friedl, P.; Wolf, K.; Lammerding, J. Nuclear envelope rupture and repair during cancer cell migration. Science 2016, 352, 353-358. [CrossRef] [PubMed]

92. Kraning-Rush, C.M.; Carey, S.P.; Lampi, M.C.; Reinhart-King, C.A. Microfabricated collagen tracks facilitate single cell metastatic invasion in 3D. Integr. Biol. 2013, 5, 606-616. [CrossRef] [PubMed] 
93. Hribar, K.C.; Meggs, K.; Liu, J.; Zhu, W.; Qu, X.; Chen, S. Three-dimensional direct cell patterning in collagen hydrogels with near-infrared femtosecond laser. Sci. Rep. 2015, 5, 17203. [CrossRef] [PubMed]

94. Burtch, S.R.; Sameti, M.; Olmstead, R.T.; Bashur, C.A. Rapid generation of three-dimensional microchannels for vascularization using a subtractive printing technique. J. Biophotonics 2018, 11, 1-13. [CrossRef] [PubMed]

95. Ilina, O.; Bakker, G.J.; Vasaturo, A.; Hofmann, R.M.; Friedl, P. Two-photon laser-generated microtracks in 3D collagen lattices: Principles of MMP-dependent and -independent collective cancer cell invasion. Phys. Biol. 2011, 8, 15010. [CrossRef] [PubMed]

96. Polacheck, W.J.; Chen, C.S. Measuring cell-generated forces: A guide to the available tools. Nat. Methods 2016, 13, 415-423. [CrossRef]

97. Jansen, K.A.; Atherton, P.; Ballestrem, C. Mechanotransduction at the cell-matrix interface. Semin. Cell Dev. Biol. 2017, 71, 75-83. [CrossRef] [PubMed]

98. Whitesides, G.M.; Ostuni, E.; Jiang, X.; Ingber, D.E. Soft lithography in biology and biochemistry. Annu. Rev. Biomed. 2001, 3, 335-373. [CrossRef]

99. Vandenburgh, H.; Shansky, J.; Benesch-Lee, F.; Barbata, V.; Reid, J.; Thorrez, L.; Valentini, R.; Crawford, G. Drug-screening platform based on the contractility of tissue-engineered muscle. Muscle Nerve 2008, 37, 438-447. [CrossRef]

100. Sakar, M.S.; Eyckmans, J.; Pieters, R.; Eberli, D.; Nelson, B.J.; Chen, C.S. Cellular forces and matrix assembly coordinate fibrous tissue repair. Nat. Commun. 2016, 7, 11036. [CrossRef]

101. Buguin, A.; Chavrier, P.; Ladoux, B.; Du Roure, O.; Saez, A.; Silberzan, P. Un substrat de micropiliers pour étudier la migration cellulaire. Med. Sci. 2005, 21, 765-767. [CrossRef] [PubMed]

102. Sniadecki, N.J.; Anguelouch, A.; Yang, M.T.; Lamb, C.M.; Liu, Z.; Kirschner, S.B.; Liu, Y.; Reich, D.H.; Chen, C.S. Magnetic microposts as an approach to apply forces to living cells. Proc. Natl. Acad. Sci. USA 2007, 104, 14553-14558. [CrossRef] [PubMed]

103. Vanderburgh, J.A.; Hotchkiss, H.; Potharazu, A.; Taufalele, P.V.; Reinhart-King, C.A. Substrate stiffness heterogeneities disrupt endothelial barrier integrity in a micropillar model of heterogeneous vascular stiffening. Integr. Biol. 2018, 10, 734-746. [CrossRef] [PubMed]

104. Alapan, Y.; Younesi, M.; Akkus, O.; Gurkan, U.A. Anisotropically stiff 3D micropillar niche induces extraordinary cell alignment and elongation. Adv. Healthc. Mater. 2016, 5, 1884-1892. [CrossRef] [PubMed]

105. Rathod, M.L.; Pareek, N.; Agrawal, S.; Jaddivada, S.; Lee, D.W.; Gundiah, N. Engineered ridge and micropillar array detectors to quantify the directional migration of fibroblasts. RSC Adv. 2017, 7, 51436-51443. [CrossRef]

106. Saez, A.; Ghibaudo, M.; Buguin, A.; Silberzan, P.; Ladoux, B.B. Rigidity-driven growth and migration of epithelial cells on microstructured anisotropic substrates. Proc. Natl. Acad. Sci. USA 2007, 104, 8281-8286. [CrossRef] [PubMed]

107. Roca-Cusachs, P.; Sunyer, R.; Trepat, X. Mechanical guidance of cell migration: Lessons from chemotaxis This review comes from a themed issue on Cell adhesion and migration. Curr. Opin. Cell Biol. 2013, 25, 543-549. [CrossRef]

108. Haessler, U.; Pisano, M.; Wu, M.; Swartz, M.A.; Jain, R.K. Dendritic cell chemotaxis in 3D under defined chemokine gradients reveals differential response to ligands CCL21 and CCL19. Proc. Natl. Acad. Sci. USA 2011, 108, 5614-5619. [CrossRef]

109. Shirure, V.S.; Lezia, A.; Alonzo, L.F.; Arnold, T.; George, S.C. Low levels of physiological interstitial flow eliminate morphogen gradients and guide angiogenesis. Angiogenesis 2017, 20, 493-504. [CrossRef]

110. Beer, M.; Kuppalu, N.; Stefanini, M.; Becker, H.; Schulz, I.; Manoli, S.; Schuette, J.; Schmees, C.; Casazza, A.; Stelzle, M.; et al. A novel microfluidic 3D platform for culturing pancreatic ductal adenocarcinoma cells: Comparison with in vitro cultures and in vivo xenografts. Sci. Rep. 2017, 7, 1-12. [CrossRef]

111. Bao, G.; Tsai, H.-F.F.; Trubelja, A.; Shen, A.Q.; Bao, G. Tumour-on-a-chip: Microfluidic models of tumour morphology, growth and microenvironment. J. R. Soc. Interface 2017, 14, 20170137.

112. Sleeboom, J.J.F.; Eslami Amirabadi, H.; Nair, P.; Sahlgren, C.M.; den Toonder, J.M.J. Metastasis in context: Modeling the tumor microenvironment with cancer-on-a-chip approaches. Dis. Model. Mech. 2018, 11, dmm033100. [CrossRef] [PubMed]

113. Sun, W.; Chen, Y.; Wang, Y.; Luo, P.; Zhang, M.; Zhang, H.; Hu, P. Interaction study of cancer cells and fibroblasts on a spatially confined oxygen gradient microfluidic chip to investigate the tumor microenvironment. Analyst 2018, 143, 5431. [CrossRef] [PubMed] 
114. Mina, S.G.; Huang, P.; Murray, B.T.; Mahler, G.J. The role of shear stress and altered tissue properties on endothelial to mesenchymal transformation and tumor-endothelial cell interaction. Biomicrofluidics 2017, 11, 044104. [CrossRef] [PubMed]

115. Nagaraju, S.; Truong, D.; Mouneimne, G.; Nikkhah, M. Microfluidic tumor-vascular model to study breast cancer cell invasion and intravasation. Adv. Healthc. Mater. 2018, 7, 1-12. [CrossRef] [PubMed]

116. Truong, D.; Puleo, J.; Llave, A.; Mouneimne, G.; Kamm, R.D.; Nikkhah, M. Breast cancer cell invasion into a three dimensional tumor-stroma microenvironment. Nat. Publ. Gr. 2016, 6, 34094. [CrossRef] [PubMed]

117. Anguiano, M.; Castilla, C.; Maška, M.; Ederra, C.; Peláez, R.; Morales, X.; Muñoz-Arrieta, G.; Mujika, M.; Kozubek, M.; Muñoz-Barrutia, A.; et al. Characterization of three-dimensional cancer cell migration in mixed collagen-Matrigel scaffolds using microfluidics and image analysis. PLoS ONE 2017, 12, 0171417. [CrossRef]

118. Amirabadi, H.E.; Sahebali, S.; Frimat, J.P.; Luttge, R.; Den Toonder, J.M.J. A novel method to understand tumor cell invasion: Integrating extracellular matrix mimicking layers in microfluidic chips by Bselective curing. Biomed. Microdevices 2017, 19, 92. [CrossRef]

119. Tong, Z.; Balzer, E.M.; Dallas, M.R.; Hung, W.-C.; Stebe, K.J. Chemotaxis of cell populations through confined spaces at single-cell resolution. PLoS ONE 2012, 7, 29211. [CrossRef]

120. Ting, L.H.; Feghhi, S.; Taparia, N.; Smith, A.O.; Karchin, A.; Lim, E.; St John, A.; Wang, X.; Rue, T.; White, N.J.; et al. Contractile forces in platelet aggregates under microfluidic shear gradients reflect platelet inhibition and bleeding risk. Nat. Commun. 2019, 10. [CrossRef]

121. Truong, D.D.; Kratz, A.; Park, J.G.; Barrientos, E.S.; Saini, H.; Nguyen, T.; Pockaj, B.; Mouneimne, G.; Labaer, J.; Nikkhah, M. A human organotypic microfluidic tumor model permits investigation of the interplay between patient-derived fibroblasts and breast cancer cells. ACCR J. 2019, 79, 3139-3151. [CrossRef]

122. Chung, M.; Ahn, J.; Son, K.; Kim, S.; Jeon, N.L. Biomimetic model of tumor microenvironment on microfluidic platform. Adv. Healthc. Mater. 2017, 6, 1-7. [CrossRef] [PubMed]

123. Lee, J.-H.; Kim, S.-K.; Khawar, I.A.; Jeong, S.-Y.; Chung, S.; Kuh, H.-J. Microfluidic co-culture of pancreatic tumor spheroids with stellate cells as a novel 3D model for investigation of stroma-mediated cell motility and drug resistance. J. Exp. Clin. Cancer Res. 2018, 37, 4. [CrossRef] [PubMed]

124. Jeong, S.-Y.; Lee, J.-H.; Shin, Y.; Chung, S.; Kuh, H.-J. Co-culture of tumor spheroids and fibroblasts in a collagen matrix-incorporated microfluidic chip mimics reciprocal activation in solid tumor microenvironment. PLoS ONE 2016, 11, e0159013. [CrossRef] [PubMed]

125. Bishop, E.S.; Mostafa, S.; Pakvasa, M.; Luu, H.H.; Lee, M.J.; Wolf, J.M.; Ameer, G.A.; He, T.-C.; Reid, R.R. 3-D bioprinting technologies in tissue engineering and regenerative medicine: Current and future trends. Genes Dis. 2017, 4, 185-195. [CrossRef] [PubMed]

126. Ravnic, D.J.; Leberfinger, A.N.; Koduru, S.V.; Hospodiuk, M.; Moncal, K.K.; Datta, P.; Dey, M.; Rizk, E.; Ozbolat, I.T. Transplantation of bioprinted tissues and organs: Technical and clinical challenges and future perspectives. Ann. Surg. 2017, 266, 48-58. [CrossRef] [PubMed]

127. Jia, W.; Gungor-Ozkerim, P.S.; Zhang, Y.S.; Yue, K.; Zhu, K.; Liu, W.; Pi, Q.; Byambaa, B.; Dokmeci, M.R.; Shin, S.R.; et al. Direct 3D bioprinting of perfusable vascular constructs using a blend bioink. Biomaterials 2016, 106, 58-68. [CrossRef]

128. Tschoeke, B.; Flanagan, T.C.; Koch, S.; Harwoko, M.S.; Deichmann, T.; Ellå, V.; Sachweh, J.S.; Kellomåki, M.; Gries, T.; Schmitz-Rode, T.; et al. Tissue-engineered small-caliber vascular graft based on a novel biodegradable composite fibrin-polylactide scaffold. Tissue Eng. Part A 2009, 15, 1909-1918. [CrossRef]

129. Potter, R.F.; Groom, A.C. Capillary diameter and geometry in cardiac and skeletal muscle studied by means of corrosion casts. Microvasc. Res. 1983, 25, 68-84. [CrossRef]

130. Sarkar, S.; Cohen, N.; Sabhachandani, P.; Konry, T. Phenotypic drug profiling in droplet microfluidics for better targeting of drug-resistant tumors. Lab Chip 2015, 15, 4441-4450. [CrossRef]

131. Eduati, F.; Utharala, R.; Madhavan, D.; Neumann, U.P.; Longerich, T.; Cramer, T.; Saez-Rodriguez, J.; Merten, C.A. A microfluidics platform for combinatorial drug screening on cancer biopsies. Nat. Commun. 2018, 9, 2434. [CrossRef] [PubMed]

132. Chang, H.-C.; Lin, C.-H.; Juang, D.; Wu, H.-W.; Lee, C.-Y.; Chen, C.; Hsu, C.-H. Multilayer architecture microfluidic network array for combinatorial drug testing on 3D-cultured cells. Biofabrication 2019, 11, 035024. [CrossRef] [PubMed]

133. Mellman, I.; Coukos, G.; Dranoff, G. Cancer immunotherapy comes of age. Nature 2014, 480, 480-489. [CrossRef] [PubMed] 
134. Gabrilovich, D.I.; Ostrand-Rosenberg, S.; Bronte, V. Coordinated regulation of myeloid cells by tumours. Nat. Rev. Immunol. 2013, 12, 253-268. [CrossRef] [PubMed]

135. Provenzano, P.P.; Cuevas, C.; Chang, A.E.; Goel, V.K.; Von Hoff, D.D.; Hingorani, S.R. Enzymatic targeting of the stroma ablates physical barriers to treatment of pancreatic ductal adenocarcinoma. Cancer Cell 2012, 21, 418-429. [CrossRef] [PubMed]

136. Stylianopoulos, T.; Jain, R.K. Combining two strategies to improve perfusion and drug delivery in solid tumors. Proc. Natl. Acad. Sci. USA 2013, 110, 18632-18637. [CrossRef] [PubMed]

137. Irish, J.M.; Kotecha, N.; Nolan, G.P. Mapping normal and cancer cell signalling networks: Towards single-cell proteomics. Nat. Rev. Cancer 2006, 6, 146-155. [CrossRef]

138. Gross, A.; Schoendube, J.; Zimmermann, S.; Steeb, M.; Zengerle, R.; Koltay, P. Technologies for single-cell isolation. Int. J. Mol. Sci. 2015, 16, 16897-16919. [CrossRef]

139. Hong, J.; Edel, J.B.; DeMello, A.J. Micro- and nanofluidic systems for high-throughput biological screening. Drug Discov. Today 2009, 14, 134-146. [CrossRef]

140. Luo, T.; Fan, L.; Zhu, R.; Sun, D. Microfluidic single-cell manipulation and analysis: Methods and applications. Micromachines 2019, 10, 104. [CrossRef]

141. Wu, H.; Zhu, J.; Huang, Y.; Wu, D.; Sun, J. Microfluidic-based single-cell study: Current status and future perspective. Molecules 2018, 23, 2347. [CrossRef] [PubMed]

142. Chao, T.-C.; Ros, A. Microfluidic single-cell analysis of intracellular compounds. J. R. Soc. Interface 2008, 5 (Suppl. 2), S139-S150. [CrossRef]

143. Karakas, H.E.; Kim, J.; Park, J.; Oh, J.M.; Choi, Y.; Gozuacik, D.; Cho, Y.-K. A microfluidic chip for screening individual cancer cells via eavesdropping on autophagy-inducing crosstalk in the stroma niche. Sci. Rep. 2017, 7, 2050. [CrossRef] [PubMed]

144. Dura, B.; Dougan, S.K.; Barisa, M.; Hoehl, M.M.; Lo, C.T.; Ploegh, H.L.; Voldman, J. Profiling lymphocyte interactions at the single-cell level by microfluidic cell pairing. Nat. Commun. 2015, 6, 5940. [CrossRef] [PubMed]

145. Chen, Y.-C.; Zhang, Z.; Fouladdel, S.; Deol, Y.; Ingram, P.N.; McDermott, S.P.; Azizi, E.; Wicha, M.S.; Yoon, E. Single cell dual adherent-suspension co-culture micro-environment for studying tumor-stromal interactions with functionally selected cancer stem-like cells. Lab Chip 2016, 16, 2935-2945. [CrossRef] [PubMed]

(C) 2019 by the authors. Licensee MDPI, Basel, Switzerland. This article is an open access article distributed under the terms and conditions of the Creative Commons Attribution (CC BY) license (http://creativecommons.org/licenses/by/4.0/). 